\title{
MENINGKATKAN KETERAMPILAN BERBICARA DAN AKTIVITAS PEMBELAJARAN MELALUI METODE MENUNJUKKAN DAN BERCERITA (SHOW AND TELL) SISWA KELAS III MADRASAH IBTIDAIYAH NEGERI 4 SUKABUMI
}

\author{
Momon \\ Kementerian Agama Kabupaten Sukabumi \\ mm.momon@gmail.com
}

\begin{abstract}
Abstrak : Penelitian ini merupakan penelitian tindakan kelas untuk mengetahui adanya peningkatan keterampilan berbicara dan aktivitas pembelajaran siswa, serta prosesnya melalui penerapan metode menunjukkan dan bercerita (show and tell). Partisipan dalam penelitian ini adalah guru dan siswa kelas III A Madrasah Ibtidaiyah Negeri 4 Sukabumi tahun pelajaran 2019/2020. Data diambil melalui teknik wawancara untuk studi pendahuluan, observasi, dan studi dokumentasi. Analisis data dalam penelitian ini menggunakan teknis reduksi data, penyajian data, verifikasi data, dan menarik kesimpulan. Hasil penelitian dapat disimpulkan bahwa metode menunjukkan dan bercerita dapat meningkatkan keterampilan berbicara siswa kelas III MIN 4 Sukabumi berdasarkan nilai rata-rata pra-siklus : 60 (kurang), siklus I menjadi 70 (cukup), dan siklus II menjadi 81 (baik). Siswa yang mencapai KKM $\geq 70$, ketika pra-siklus : 4 orang (22\%), siklus I : 6 orang (33\%), dan siklus II : 16 orang (89\%). Jadi besarnya peningkatan keterampilan berbicara siswa secara klasikal $89 \%$. Metode menunjukkan dan bercerita dapat meningkatkan aktivitas pembelajaran siswa kelas III MIN 4 Sukabumi berdasarkan nilai rata-rata kinerja siswa, pada siklus I : 60 (baik) dan siklus II : 87 (sangat baik). Jadi besarnya peningkatan aktivitas pembelajaran siswa secara klasikal $87 \%$. Sedangkan proses peningkatan telah menempatkan guru dan siswa sama-sama sebagai subjek pembelajaran. Proses pembelajaran mengacu pada RPP sebagai desain pengelolaan proses pembelajaran dengan metode menunjukkan dan bercerita, mulai kegiatan pendahuluan, kegiatan inti, dan kegiatan penutup. Capaian telah melebihi indikator ketuntasan penelitian tindakan yang dipersyaratkan yaitu $75 \%$ dari jumlah siswa mencapai kriteria ketuntasan minimal (KKM), maka penelitian tindakan dihentikan dan selesai.
\end{abstract}

Kata Kunci : Menunjukkan dan bercerita, keterampilan berbicara, aktivitas pembelajaran

\section{A. PENDAHULUAN}

Keterampilan berbicara merupakan aspek yang sangat penting yang harus dikembangkan agar seseorang mampu berkomunikasi dengan baik. Allah SWT. berfirman dalam Surat Ar-Rahman (55) Ayat 3 dan 4:

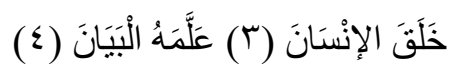

"Dia menciptakan manusia, mengajarnya pandai berbicara” (Q.S. 55:3-4).
Ayat tersebut menegaskan bahwa kemampuan berbicara itu sangat utama dan sangat istimewa bagi manusia. Menurut Arief (2016) sumber daya manusia harus memiliki kemampuan untuk berinteraksi secara efektif dengan orang lain, termasuk kemampuan mendengar dan berkomunikasi. Kompetensi ini merupakan upaya yang harus diperhatikan dalam meningkatkan mutu sumber daya manusia.

Mutu sumber daya manusia dapat dibentuk melalui pendidikan. Pendidikan direalisasikan melalui pembelajaran yang dilaksanakan secara kelembagaan. Dalam tataran implementasi, terdapat tiga bentuk 
lembaga pendidikan, yaitu pendidikan formal, pendidikan non formal, dan pendidikan informal. Salah satu lembaga pendidikan formal adalah Madrasah Ibtidaiyah. Madrasah Ibtidaiyah adalah sekolah dasar di bawah binaan Kementerian Agama yang menyelenggarakan pendidikan umum dengan kekhasan Agama Islam. Sama seperti sekolah dasar lainnya di Madrasah Ibtidaiyah semua siswa diberi pembelajaran awal yang lebih mendasar dan nantinya akan dilanjutkan ke jenjang yang lebih tinggi.

Siswa Madrasah Ibtidaiyah banyak belajar dan berlatih berbagai hal dalam proses pendidikannya. Materi pembelajaran dikemas dalam mata pelajaran dan tema-tema yang mengintegrasikan berbagai muatan pembelajaran. Salah satu muatan pembelajarannya adalah mata pelajaran Bahasa Indonesia. Terdapat empat kompetensi yang diajarkan bagi peserta didik dalam muatan pembelajaran Bahasa Indonesia yaitu membaca, menulis, menyimak, dan berbicara. Khusus dalam pembelajaran berbicara, peserta didik diajarkan bagaimana cara berbicara dalam keterampilan berkomunikasi.

Dalam Silabus Bahasa Indonesia Kurikulum 2013 untuk SD/MI dinyatakan bahwa ruang lingkup Bahasa Indonesia adalah menggunakan bahasa secara efektif dan efisien sesuai dengan etika yang berlaku, baik secara lisan maupun tulis, menghargai dan bangga menggunakan bahasa Indonesia sebagai bahasa persatuan dan bahasa negara serta menggunakannya dengan tepat dan kreatif untuk berbagai tujuan. Dengan kata lain salah satu dari tujuan mata pelajaran bahasa Indonesia adalah berkomunikasi secara efektif dan efisien sesuai dengan etika yang berlaku, baik secara lisan maupun tulis (Kemendikbud, 2016).

Dalam proses pembelajaran Bahasa Indonesia, siswa dituntut untuk berlatih terampil berbicara, mampu mengungkapkan pendapat, mampu menjawab pertanyaan atau mengajukan pertanyaan dengan baik selama pembelajaran berlangsung. Ketika melaksanakan diskusi, siswa dituntut terampil mengutarakan pendapat, mempertahankan pendapat dan menyanggah pendapat siswa lain.
Mengembangkan potensi peserta didik agar memiliki keterampilan berbicara melalui proses pembelajaran merupakan upaya membangun kemampuan. Menurut Tarigan (2015) Keterampilan hanya bisa diperoleh dan dikuasai dengan jalan praktik dan banyak latihan. Kemampuan berbicara dilatih agar mempermudah memahami dalam berkomunikasi, untuk melatih keterampilan berbicara tentunya dimulai sejak dini yaitu di lingkungan sekolah tempat di mana peserta didik belajar. Keterampilan berbicara dikembangkan secara terus menerus maka semakin lama akan semakin sempurna, dalam artian strukturnya menjadi benar, kalimatkalimatnya semakin bervariasi, kosa kata yang semakin banyak, lalu pilihan katanya semakin tepat dan sebagainya.

Hasil studi awal penulis selama menjadi Pengawas Madrasah dan terakhir pada bulan maret 2019 pada kegiatan observasi kelas dalam rangka Penilaian Kinerja Guru (PKG) Madrasah Ibtidaiyah di Kecamatan Palabuhanratu kabupaten Sukabumi terdapat beberapa temuan pada saat proses pembelajaran berlangsung, secara umum dalam proses pembelajaran siswa pasif, mayoritas peserta didik belum berani bertanya, ada pertanyaan hanya diam, belum beranii berbicara di depan kelas, tidak berani untuk mengemukakan pendapat, tidak percaya diri saat berbicara, pelafalan yang kurang jelas, berbicara kurang lancar, kosa kata yang masih terbatas. Kurangnya keterampilan berkomunikasi yang dimiliki oleh siswa tersebut membuat aktivitas belajar berpusat pada guru (teacher active learning). Siswa hanya mengikuti arahan-arahan guru saja. Kondisi inii mengakibatkan aktivitas belajar monoton sehingga kompetensi dan tujuan pembelajaran sulit dicapai.

Berdasarkan temuan tersebut, maka harus ada solusi untuk mengatasi kesulitan dan kelemahan dalam proses pembelajaran. Guru harus menyajikan pembelajaran dengan metode dan media yang tepat, variatif, menyenangkan, menarik, dan kontekstual. Siswa dituntut aktif dan merasa nyaman ketika belajar dan terlatih berbicara di depan kelas. 
Oleh karena itu, dengan adanya permasalahan sebagaimana uraian di atas, penulis berpikir bahwa proses pembelajaran keterampilan berbicara harus ditingkatkan kualitasnya melalui penerapan metode yang tepat. Salah satu metode yang diyakini mampu meningkatkan keterampilan berbicara adalah metode menunjukkan dan bercerita (show and tell). Metode menunjukkan dan bercerita adalah kegiatan pembelajaran yang memperlihatkan berbagai benda lalu diamati dan diceritakan yang berhubungan dengan benda tersebut, atau menyampaikan pengalaman-pengalaman terkait dengan benda tersebut kepada teman-temannya. Menurut Amode Taher (dalam Musfiroh, 2018) penerapan metode ini adalah dengan memanfaatkan benda nyata, lalu semua siswa mengamatinya dan menceritakan temuan sekitar benda itu, sehingga seluruh siswa aktif dalam kegiatan pembelajaran.

Berdasarkan uraian di atas, peneliti sangat tertarik untuk melakukan penelitian tindakan kepengawasan sebagai kegiatan supervisi akademik dengan mendesain pembelajaran bagi guru agar melakukan penelitian tindakan kelas dengan menerapkan metode menunjukkan dan bercerita untuk meningkatkan keterampilan berbicara dan aktivitas pembelajaran siswa kelas III Madrasah Ibtidaiyah Negeri 4 Sukabumi yang menjadi madrasah binaan peneliti di Kecamatan Palabuhanratu Kabupaten Sukabumi. Dengan metode ini diharapkan siswa lebih terlatih dalam keterampilan berbicara dan aktivitas pembelajaran semakin baik..

\section{Keterampilan Berbicara}

Banyak para ahli yang telah memberikan pengertian keterampilan berbicara. Iskandarwassid dan Suhendar (2011) menjelaskan bahwa keterampilan berbicara pada esensinya merupakan keterampilan memproduksi arus sistem bunyi artikulasi untuk menyatakan kehendak, perasaan, dan keinginan kepada orang lain. Kelengkapan alat ucap seseorang merupakan persyaratan yang utama untuk memproduksi suatu ragam yang luas sebagai bunyi artikulasi, nada, tekanan, dan gaya bicara. Keterampilan berbicara juga termasuk kepercayaan diri untuk berbicara dengan baik, jujur, benar, dan bertanggung jawab, dengan tidak mengalami masalah psikologis seperti rasa malu, tegang, rendah diri, dan lain-lain.

Tarigan (2015) mengungkapkan bahwa keterampilan berbicara adalah kemampuan melafalkan vokal artikulasi dan kata-kata untuk mengungkapkan dan menyampaikan gagasan, pendapat, dan perasaan hati. Berbicara sebagai alat untuk menyampaikan ide-ide sesuai dengan kebutuhan si pembicara dan si pendengar. Bahkan berbicara sebagai instrumen untuk mengungkapkan pikiranpikiran secara langsung sehingga apakah si pembicara atau si pendengar mampu memahami atau tidak terhadap yang disampaikan atau didengarkannya.

$$
\text { Arsjad dan Mukti }
$$
menyampaikan bahwa berbicara adalah kemampuan melafalkan bunyi-bunyi artikulasi dan mengungkapkan kata-kata untuk mengeluarkan dan menyampaikan pikiran, ide, dan perasaan si pembicara. Berbicara merupakan aktivitas komunikasi yang utama dalam kehidupan interaksi antara manusia. Melalui berbicara setiap orang dapat saling berkomunikasi untuk menyampaikan ide, tujuan dan pesan, serta menyampaikan perasaan hati (Kusuma, 2009).

Merujuk kepada pendapat-pendapat di atas, maka peneliti dapat mengambil kesimpulan bahwa keterampilan berbicara merupakan sebuah kemampuan seseorang dalam berkomunikasi dengan mengucapkan kata-kata untuk mengungkapkan, menyatakan, mengeluarkan pikiran, ide, dan perasaan kepada orang lain.

Adapun untuk menilai sejauhmana kemampuan siswa dalam keterampilan berbicara, penulis merujuk kepada rumusan para ahli yaitu Arsjad dan Mukti (2005), Arsjad (dalam Resmini dan Juanda, 2007), Nurgiyantoro (2010), dan Tarigan (2015) yaitu dengan menilai indikator kemampuan berbicara siswa sebagai berikut :

\section{Unsur Kebahasaan}

a) Lafal yaitu mengucapkan bunyi-bunyi bahasa secara sesuai;

b) Intonasi (tekanan) yaitu tinggi rendahnya, panjang pendeknya, atau keras lembutnya suara atau pengucapan; 
c) Kosa kata (diksi) yaitu penggunaan kata baku atau kata yang baik dan benar, kata yang mudah dimengerti.

\section{Unsur Non kebahasaan}

a) Kelancaran yaitu tidak terbata-bata pada saat berbicara di depan umum;

b) Gestur yaitu aksi tubuh dalam mengkomunikasikan pesan;

c) Sikap yaitu etika yang dilakukan ketika berbicara;

d) Ketepatan isi cerita yaitu isi cerita sesuai dan mudah dipahami (menceritakan benda yang dibawa/diamati);

e) Pemahaman yaitu paham terhadap apa yang disampaikan.

\section{Aktivitas Pembelajaran}

Mulyono (2011) berpendapat bahwa aktivitas artinya kegiatan atau keaktifan. Jadi segala sesuatu yang dilakukan atau kegiatankegiatan yang terjadi baik fisik maupun nonfisik, merupakan suatu aktifitas. Menurut Sriyono (2012) aktivitas adalah segala kegiatan yang dilaksanakan baik secara jasmani atau rohani. Aktivitas siswa selama proses pembelajaran merupakan salah satu indikator adanya keinginan siswa untuk belajar. Aktivitas siswa merupakan kegiatan atau perilaku yang terjadi selama proses belajar mengajar. Kegiatan-kegiatan yang dimaksud adalah kegiatan yang mengarah pada proses belajar seperti bertanya, mengajukan pendapat, mengerjakan tugastugas, dapat menjawab pertanyaan guru dan bisa bekerjasama dengan siswa lain, serta tanggung jawab terhadap tugas yang diberikan. Keaktifan siswa dalam proses pembelajaran akan menyebabkan interaksi yang tinggi antara guru dengan siswa ataupun dengan siswa itu sendiri. Hal ini akan mengakibatkan suasana kelas menjadi segar dan kondusif, di mana masing-masing siswa dapat melibatkan kemampuannya semaksimal mungkin.

Aktivitas yang timbul dari siswa akan mengakibatkan pula terbentuknya pengetahuan dan keterampilan yang akan mengarah pada peningkatan prestasi. Aktivitas belajar merupakan suatu kegiatan yang dilakukan untuk menghasilkan perubahan pengetahuan-pengetahuan, nilainilai sikap, dan keterampilan pada siswa sebagai latihan yang dilaksanakan secara sengaja (Sriyono, 2012).

Aktivitas yang dimaksudkan di sini penekanannya adalah pada siswa, sebab dengan adanya aktivitas siswa dalam proses pembelajaran terciptalah situasi belajar aktif, seperti yang dikemukakan oleh Natawijaya (2005), belajar aktif adalah Suatu sistem belajar mengajar yang menekankan keaktifan siswa secara fisik, mental intelektual dan emosional guna memperoleh hasil belajar berupa perpaduan antara aspek koqnitif, afektif dan psikomotor.

Keaktifan siswa selama proses belajar mengajar merupakan salah satu indikator adanya keinginan atau motivasi siswa untuk belajar. Siswa dikatakan memiliki keaktifan apabila ditemukan ciri-ciri perilaku seperti : sering bertanya kepada guru atau siswa lain, mau mengerjakan tugas yang diberikan guru, mampu menjawab pertanyaan, senang diberi tugas belajar, dan lain sebagainya. Keaktifan siswa dalam proses pembelajaran akan menyebabkan interaksi yang tinggi antara guru dengan siswa ataupun dengan siswa itu sendiri. Hal ini akan mengakibatkan suasana kelas menjadi segar dan kondusif, di mana masing-masing siswa dapat melibatkan kemampuannya semaksimal mungkin. Aktivitas yang timbul dari siswa akan mengakibatkan pula terbentuknya pengetahuan dan keterampilan yang akan mengarah pada peningkatan prestasi.

Berdasarkan pengertian di atas, penulis dapat menyimpulkan bahwa aktivitas belajar merupakan segala kegiatan yang dilakukan dalam proses interaksi pembelajaran baik yang berhubungan dengan kinerja guru maupun kinerja siswa dalam proses pembelajaran dari mulai kegiatan pendahuluan, kegiatan inti, dan kegiatan penutup dalam rangka mencapai tujuan pembelajaran.

\section{Metode Menunjukkan dan Bercerita (Show and Tell)}

Musfiroh (2018) memberikan pengertian bahwa metode menunjukkan dan bercerita (show and tell) adalah kegiatan untuk menunjukkan sesuatu pada pendengar dan menjelaskan atau menggambarkan 
sesuatu yang telah ditemukannya. Menurut Tilaar (2013) yang dimaksud dengan metode menunjukkan dan bercerita adalah suatu kegiatan yang mengutamakan kemampuan siswa dalam berkomunikasi sederhana. Tujuan dari kegiatan ini adalah untuk melatih siswa belajar berbicara di depan kelas atau membiasakan siswa peka terhadap hal-hal sederhana pada kehidupan sehari-hari.

Sedangkan, Suryanto

(2005) mengungkapkan bahwa metode menunjukkan dan bercerita diterapkan untuk mengungkapkan temuan, perasaan, dan keinginan siswa. Untuk lebih memahami lagi. Suarsih (2018) menyatakan metode menunjukkan dan bercerita merupakan kegiatan untuk menunjukkan sesuatu kepada pendengar dan menjelaskan atau menggambarkan sesuatu kepada orang lain. Dalam realitasnya metode menunjukkan dan bercerita digunakan untuk tiga ranah yaitu untuk berbicara, untuk bermain boneka, dan untuk bercerita.

Musfiroh (2018), menyatakan terdapat beberapa jenis metode menunjukkan dan bercerita yang dapat dilaksanakan, yaitu menunjukkan dan bercerita dengan menggunakan benda pribadi, menunjukkan dan bercerita dengan menggunakan makanan, dan menunjukkan dan bercerita dengan menggunakan gambar atau foto.

Adapun langkah-langkah dari metode tersebut dikemukakan oleh Dananjaya (2011) yaitu:

1. Persiapan

a) Guru menugaskan siswa untuk membawa benda-benda kecil yang disayangi yang ada di rumahnya.

b) Siswa ditugaskan untuk mencari tahu informasi tentang benda itu dengan cara bertanya kepada anggota keluarganya.

2. Pelaksanaan

a) Seluruh benda diletakkan di suatu tempat (meja/depan kelas)

b) Secara berurutan, setiap siswa menjelaskan segala hal tentang benda yang dibawanya. Teman-temannya boleh bertanya.

c) Setiap seorang siswa selesai, temantemannya memberi tepuk tangan.
3. Refleksi

a) Perhatikan apakah siswa senang dan bersemangat dalam menceritakan kisah di balik benda yang dibawanya.

b) Bagaimana respon mereka terhadap barang bawaan teman yang lain; apakah siswa juga menaruh perhatian yang sama besarnya seperti pada benda miliknya.

c) Analisislah, apakah tujuan yang diinginkan sudah tercapai.

\section{B. METODOLOGI PENELITIAN}

Dalam penilitian ini metode yang digunakana adalah Metode Penelitian Tindakan Kelas (Class Action Research) Model Kemmis dan Mc Taggart (Arikunto, 2013, Arief, 2017) yaitu penelitian yang bersifat reflektif dengan melakukan tindakan tertentu agar dapat memperbaiki atau meningkatkan paraktek pembelajaran yang lebih baik, yang dilakukan melalui siklus mulai dari perencanaan tindakan, pelaksanaan tindakan, pengamatan (observasi), dan refleksi.

Partisipan dalam penelitian ini adalah siswa kelas IIIA Madrasah Ibtidaiyah Negeri 4 Sukabumi yang beralamat di Kp. Cikondanglaya RT.04/05 Desa Tonjong Kecamatan Palabuhanratu Kabupaten Sukabumi Tahun Pelajaran 2019/2020 dengan jumlah siswa 18 orang terdiri dari 9 orang laki-laki dan 9 orang perempuan. Data diambil melalui teknik wawancara untuk studi pendahuluan, observasi, dan studi dokumentasi. Analisis data dalam penelitian ini menggunakan teknis reduksi data, penyajian data, verifikasi data, dan menarik kesimpulan.

\section{HASIL DAN PEMBAHASAN}

Penelitian Tindakan Kelas (PTK) dilaksanakan di kelas IIIA MIN 4 Sukabumi pada pembelajaran Bahasa Indonesia, Tema 1 : Perkembangbiakan Hewan da Tumbuhan, sub tema 3 : Pelestarian Hewan dan Tumbuhan Langka, pada minggu ke empat bulan Juli sampai minggu ke dua bulan Agustus 2019 yang dilaksanakan dalam dua siklus, yang diawali dengan tindakan prasiklus, siklus I, dan siklus II dengan harapan 
dapat meningkatkan keterampilan berbicara dan aktivitas pembelajaran siswa.

Berikut penulis uraikan hasil penelitian tindakan setelah diterapkannya metode menunjukkan dan bercerita (show and tell) :

\section{Peningkatan Keterampilan Berbicara Siswa}

Terjadi peningkatan yang signifikan keterampilan berbicara siswa setelah diterapkannya metode menunjukkan dan bercerita (show and tell) yang penulis nyatakan dalam tabel berikut.

Tabel 1 Keterampilan Berbicara Siswa Hasil Pra-siklus, Siklus I, dan Siklus II

\begin{tabular}{|c|c|c|c|c|c|}
\hline \multirow[b]{2}{*}{ No } & \multirow[b]{2}{*}{ Nama Siswa } & \multicolumn{3}{|c|}{ NILAI RATA-RATA } & \multirow{2}{*}{$\begin{array}{c}\text { KATE } \\
\text { GORI } \\
\geq 70\end{array}$} \\
\hline & & $\begin{array}{c}\text { PRA- } \\
\text { SIKLUS }\end{array}$ & $\begin{array}{c}\text { SIKLUS } \\
\text { I }\end{array}$ & $\begin{array}{c}\text { SIKLUS } \\
\text { II }\end{array}$ & \\
\hline 1 & Andika Surya & 55 & 63 & 68 & BT \\
\hline 2 & Dede Risti & 58 & 68 & 75 & $\mathrm{~T}$ \\
\hline 3 & Indah Julianti & 70 & 83 & 90 & $\mathrm{~T}$ \\
\hline 4 & Indrayana & 53 & 60 & 78 & $\mathrm{~T}$ \\
\hline 5 & Indriyani & 55 & 60 & 68 & BT \\
\hline 6 & M. Azam & 58 & 68 & 75 & $\mathrm{~T}$ \\
\hline 7 & M. Ibnu Sabil & 58 & 68 & 75 & $\mathrm{~T}$ \\
\hline 8 & M. Raihan & 55 & 63 & 70 & $\mathrm{~T}$ \\
\hline 9 & Moch. Adityai & 70 & 83 & 85 & $\mathrm{~T}$ \\
\hline 10 & Pinca Alvarizi & 58 & 68 & 70 & $\mathrm{~T}$ \\
\hline 11 & Putri Nur Aprilia & 70 & 83 & 90 & $\mathrm{~T}$ \\
\hline 12 & Rahayu Herfiani & 55 & 63 & 90 & $\mathrm{~T}$ \\
\hline 13 & Sabrina Ayu & 73 & 88 & 93 & $\mathrm{~T}$ \\
\hline 14 & Safana Nurazalia & 60 & 75 & 90 & $\mathrm{~T}$ \\
\hline 15 & Triska Maulida & 58 & 68 & 85 & $\mathrm{~T}$ \\
\hline 16 & Zidny Rajkia & 60 & 73 & 88 & $\mathrm{~T}$ \\
\hline 17 & Rangga & 58 & 68 & 75 & $\mathrm{~T}$ \\
\hline \multirow[t]{8}{*}{18} & Muhamad Padzril & 58 & 68 & 90 & $\mathrm{~T}$ \\
\hline & Jumlah & 1082 & 1270 & 1455 & \multirow{7}{*}{$\begin{array}{l}\text { TUN } \\
\text { TAS }\end{array}$} \\
\hline & $\begin{array}{c}\text { Jumlah Siswa } \\
\text { Tuntas }\end{array}$ & 4 & 6 & 16 & \\
\hline & $\%$ Ketuntasan & $22 \%$ & $33 \%$ & $89 \%$ & \\
\hline & Nilai Terendah & 53 & 60 & 68 & \\
\hline & Nilai Tertinggi & 73 & 88 & 93 & \\
\hline & Nilai Rata-rata & 60 & 70 & 81 & \\
\hline & Kategori & BT & BT & $\mathbf{T}$ & \\
\hline
\end{tabular}

Peningkatan kemampuan keterampilan berbicara siswa hasil pra-siklus, hasil tindakan siklus I, dan Siklus II sebagaimana

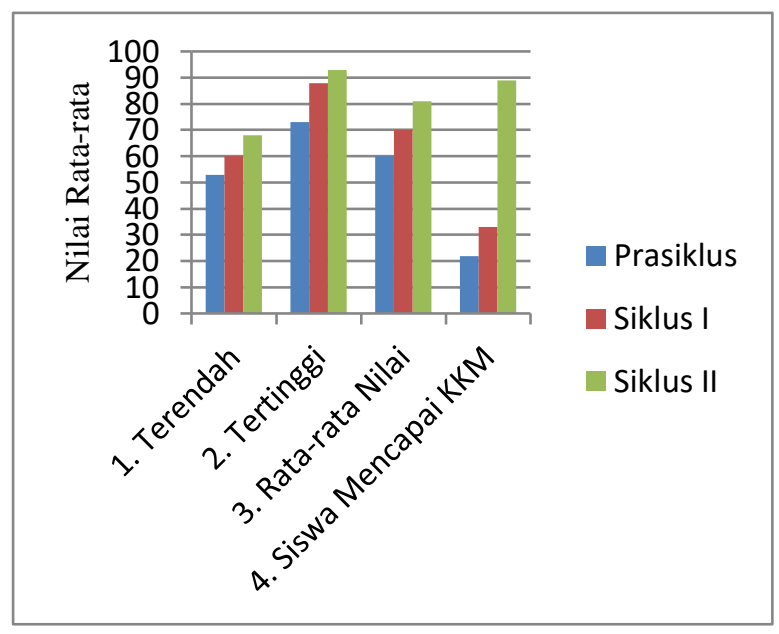

Grafik 1 Nilai Keterampilan Berbicara Siswa Prasiklus, Siklus I, dan II

tabel 1 di atas, penulis dapat gambarkan dengan grafik berikut.

Adapun capaian dari setiap indikator keterampilan berbicara siswa menunjukkan terjadinya peningkatan pada setiap indikator pada pra-siklus, siklus I, dan siklus II yang penulis gambarkan melalui grafik berikut.

\section{Peningkatan Aktivitas Pembelajaran Siswa}

Data peningkatan aktivitas pembelajaran siswa berdasarkan peningkatan kinerja siswa pada siklus I dan II, penulis sajikan dalam tabel berikut.

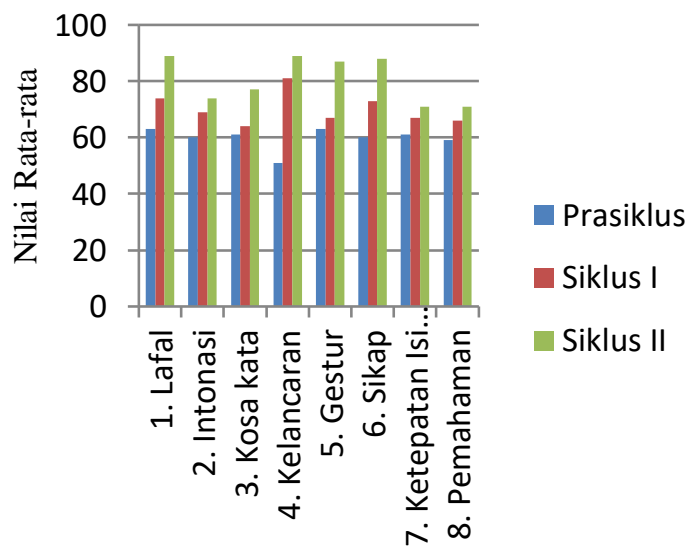

Grafik 2 Indikator Keterampilan Berbicara Siswa Hasil Pa-siklust, Tindakan Siklus I, dan Siklus II 
Tabel 2 Peningkatan Aktivitas Pembelajaran Hasil Siklus I dan Siklus II

\begin{tabular}{|c|c|c|c|c|c|}
\hline $\begin{array}{l}\mathbf{N} \\
\mathbf{0}\end{array}$ & $\begin{array}{c}\text { Tahap } \\
\text { an }\end{array}$ & $\begin{array}{l}\text { Aspek yang } \\
\text { diamati }\end{array}$ & $\begin{array}{c}\text { Rata- } \\
\text { rata } \\
\text { Nilai } \\
\text { Siklus } \\
\text { I }\end{array}$ & $\begin{array}{c}\text { Rata- } \\
\text { rata } \\
\text { Nilai } \\
\text { Siklus } \\
\text { II } \\
\end{array}$ & $\underset{\mathrm{ri}}{\text { Katego }}$ \\
\hline \multirow[t]{4}{*}{1} & \multirow[t]{4}{*}{$\begin{array}{l}\text { Penda } \\
\text { hulu } \\
\text { an }\end{array}$} & \begin{tabular}{|l|} 
a. Siswa \\
berdo'a \\
bersama, \\
penguatan \\
pendidikan \\
karakter, \\
dan literasi \\
\end{tabular} & 76 & 98 & $\begin{array}{c}\text { Sangat } \\
\text { Baik }\end{array}$ \\
\hline & & \begin{tabular}{|l|} 
b. \\
Siswa \\
menyimak \\
penyampaia \\
n guru \\
kaitan \\
tema/sub \\
tema, \\
pembelajar \\
an, dan \\
fokus \\
pembelajar \\
an. \\
\end{tabular} & 58 & 90 & $\begin{array}{c}\text { Sangat } \\
\text { Baik }\end{array}$ \\
\hline & & \begin{tabular}{|l} 
c. Siswa \\
menyimak \\
penyampaia \\
n guru \\
kaitan \\
kompetensi, \\
tujuan, dan \\
manfaat \\
yang akan \\
dicapai, \\
serta \\
rencana \\
kegiatan \\
pembelajar \\
an yang \\
akan \\
dilaksanaka \\
n.
\end{tabular} & 58 & 79 & Baik \\
\hline & & 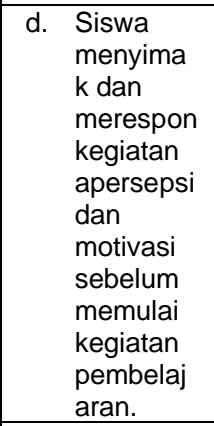 & 58 & 77 & Baik \\
\hline 2 & Inti & $\begin{array}{l}\text { a. Siswa } \\
\text { membaw } \\
\text { a benda } \\
\text { kesayang } \\
\text { annya, } \\
\text { menyimp } \\
\text { annya di } \\
\text { atas meja } \\
\text { lalu siswa } \\
\text { mengama } \\
\text { ti } \\
\text { sekaligus } \\
\text { mengump } \\
\text { ulkan } \\
\text { informasi } \\
\text { kaitan } \\
\text { benda }\end{array}$ & 74 & 97 & $\begin{array}{c}\text { Sangat } \\
\text { Baik }\end{array}$ \\
\hline
\end{tabular}

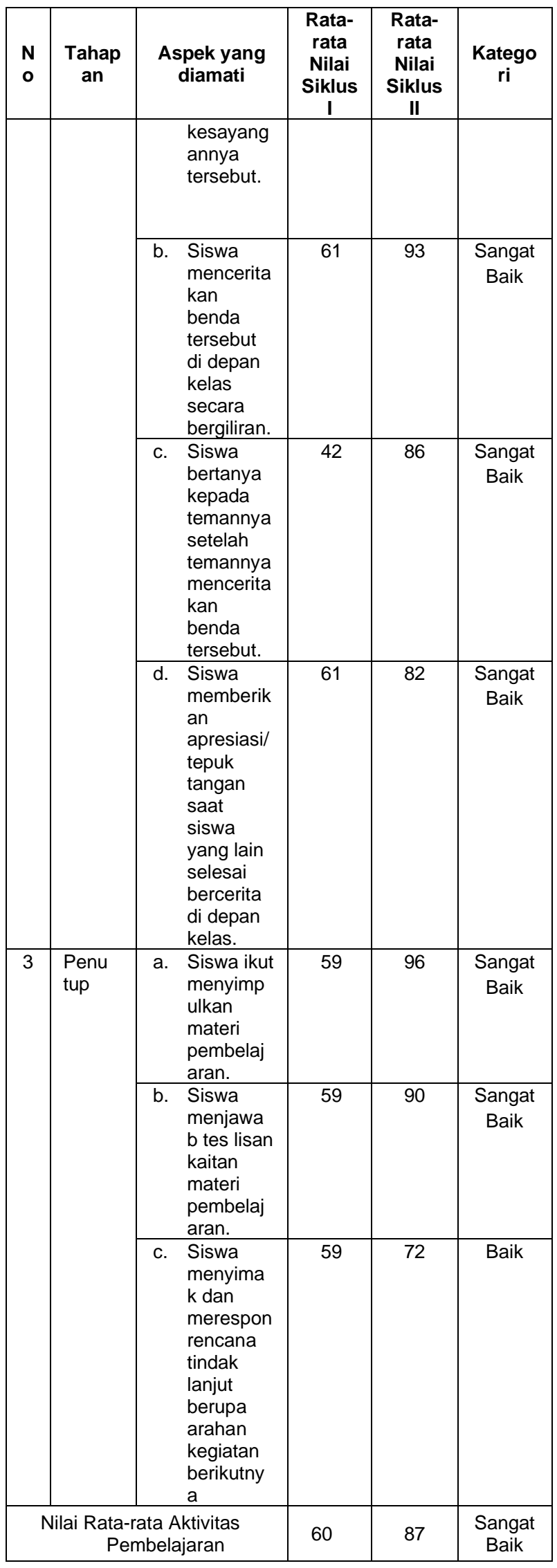

Peningkatan aktivitas pembelajaran siswa hasil tindakan siklus I dan Siklus II 
sebagaimana tabel 4.2 di atas, penulis dapat gambarkan dengan grafik berikut.

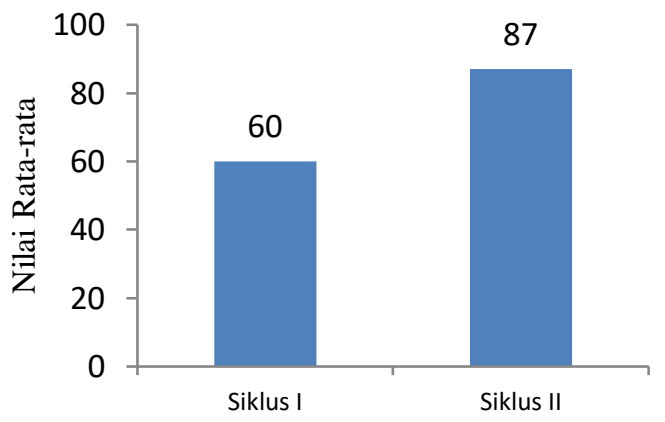

Grafik 3 Peningkatan Aktivitas Pembelajaran Siswa Hasil Siklus I dan Siklus

\section{KESIMPULAN DAN SARAN}

Berdasarkan deskripsi, analisis data, interpretasi dan pembahasan hasil penelitian, penulis dapat mengambil kesimpulan sebagai berikut.

1. Metode menunjukkan dan bercerita telah terbukti dapat meningkatkan keterampilan berbicara siswa kelas III MIN 4 Sukabumi, berdasarkan nilai ratarata pra-siklus: 60 (kurang), siklus I menjadi 70 (cukup), dan siklus II menjadi 81 (baik). Siswa yang mencapai KKM?70, ketika pra-siklus: 4 orang $(22 \%)$, siklus I : 6 orang (33\%), dan siklus II : 16 orang $(89 \%)$. Jadi besarnya peningkatan keterampilan berbicara siswa secara klasikal $89 \%$.

2. Metode menunjukkan dan bercerita telah terbukti dapat meningkatkan aktivitas pembelajaran siswa kelas III MIN 4 Sukabumi, berdasarkan nilai rata-rata kinerja siswa, pada siklus I : 60 (baik) dan siklus II : 87 (sangat baik). Jadi besarnya peningkatan aktivitas pembelajaran siswa secara klasikal $85 \%$.

3. Proses peningkatan keterampilan berbicara siswa dan aktivitas pembelajaran melalui penerapan metode menunjukkan dan bercerita di kelas III MIN 4 Sukabumi telah menempatkan guru dan siswa sama-sama sebagai subjek belajar. Guru melaksanakan proses pembelajaran dengan runtut mengacu kepada RPP sebagai desain pengelolaan proses pembelajaran mulai dari kegiatan pendahuluan, kegiatan inti, dan kegiatan penutup. Pembelajaran berlangsung aktif, kreatif, efektif, dan menyenangkan, serta gembira dan berbobot (Pakem Gembrot) sehingga terjadi peningkatan keterampilan berbicara dan aktivitas pembelajaran siswa.

\section{DAFTAR PUSTAKA}

Arief, Zainal Abidin. (2017). Kawasan

Penelitian Teknologi Pendidikan. Studi

Aneka Sumber Belajar yang

Berorientasi pada Student Centre dan

Student Creator. Bogor: UIKA Press. (2016). Teknologi Kinerja

dalam Proses Pembelajaran. Bogor:

UIKA Press.

Arikunto, Suharsimi. (2013). Prosedur

Penelitian. Suatu Pendekatan Praktik.

Jakarta: Rineka Cipta.

Arsjad dan Mukti. (2005). Pembinaan

Kemampuan Berbicara Bahasa

Indonesia. Jakarta: Erlangga.

Dananjaya, Utomo. (2011). Media

Pembelajaran Aktif. Bandung: Nuansa.

Departemen Agama RI. (2006). Al-Quran

dan Terjemahannya. Bandung: CV

Diponegoro.

Kemendikbud. (2016). Silabus Sekolah

Dasar/Madrasah Ibtidaiyah (SD/MI)

Tematik Terpadu. Jakarta:

Kemendikbud.

Kusuma, Wijaya. (2009). Mengenal

Penelitian Tindakan Kelas. Jakarta: PT

Indek.

Iskandarwassid dan Suhendar. (2011).

Strategi Pembelajaran Bahasa.

Bandung: Remaja Rosdakarya.

Mulyono, Abdurrahman. (2011). Pendidikan

Bagi Anak Berkesulitan Belajar.

Jakarta: Rineka Cipta. 
Musfiroh, Takdiroatun. (2018). Show and

Tell Edukatif: Panduan

Pengembangan Social Skill Anak Usia

Dini. Jakarta: Tiara Wacana.

Natawijaya, Rochman. (2005). Aktivitas

Belajar. Jakarta: Depdiknas.

Nurgiyantoro, Burhan. (2010). Penilaian

Pembelajaran Bahasa. Yogyakarta:

Universitas Negeri Yogyakarta.

Resmini, Novi dan Dadan Juanda, (2007).

Pendidikan Bahasa dan Sastra

Indonesia di Kelas Tinggi. Bandung:

UPI Press.

Sriyono. (2012). Aktivitas Belajar Siswa.

Jakarta: Rineka Cipta.

Suarsih, Cicih. (2018). Upaya Meningkatkan

Keterampilan Berbicara Siswa Dengan

Menerapkan Metode Show And Tell

Pada Pembelajaran Bahasa dan Sastra

Indonesia. Penelitian Tindakan Kelas

Pada Siswa Kelas II di SD Negeri

Sumurbarang Kecamatan Cibogo

Kabupaten Subang Tahun Pelajaran

2016/2017.

Suryanto, Selamat. (2005). Dasar-dasar

Pendidikan Anak Usia Dini.

Yogyakarta: Hikayat Publishing.

Tarigan, Henry Guntur. (2015). Berbicara

Sebagai Suatu Keterampilan

Berbahasa. Bandung: Angkasa.

Tilaar, H.A.R. (2013). Manajemen

Pendidikan Nasional. Bandung:

Rosdakarya. 